\begin{abstract}
:
Our current political climate has made the campus climate on many universities increasingly hostile. As an assistant professor at a research-intensive university, I outline what it means to be a woman of color in a vulnerable academic discipline in the context of conservative state politics and the rise of the Alt-Right. I argue that the current political climate in which white supremacists have been emboldened, academic freedom attacked, and funding to institutions of higher education cut, has especially negative repercussions for minority academics in largely white institutions.
\end{abstract}




\section{Fomenting Fear and Calling on Our Courage: Being Latinx on the Tenure Track in the Time of Trumpism}

"Don't be safe. Because there is no safety there anyway" Sarita Echavez See

This quote by Echavez See $(2016,148)$ challenges us to heed the lessons of Audre Lorde ("your silence will not protect you") as we navigate the processes of tenure. I am an assistant professor in Women's and Gender Studies at an R1 (research intensive) university in the Midwest, United States. And I will know the result of my tenure decision next spring. Being Latinx in a Women's and Gender Studies (WGS) department—which is a relatively new field compared to most — has illuminated a number of interrelated obstacles for me as a woman scholar in a marginalized field in the time of Trumpism. Our current political climate is one where President Trump has called Mexican immigrants "rapists" and "criminals", has supported sexual assault ("grab 'em by the pussy"), and has said of white supremacists marching in Charlottesville that some were "very fine people." These comments and many more have emboldened white supremacists, making them more vocal and dangerous. This charged climate extends to college campuses. Just recently, for example, fliers by an Alt-Right white supremacist group, encouraging students to join their movement, were found on my university.

In this essay I outline what it means to be a woman of color in a vulnerable academic discipline in the context of conservative state politics and the rise of the Alt-Right. I then discuss how these politics have shaped my experiences on the tenure track, and I offer suggestions for how to best support scholars like myself through the use of a feminist mentoring framework. Specifically, I argue that the current political climate in which white supremacists have been emboldened, academic freedom attacked, and funding to institutions of higher education cut, has especially negative repercussions for minority academics in largely white institutions. 


\section{On the Margins}

Women's and Gender Studies departments have held marginalized positions within research universities since their establishment during the Second Wave feminist movement. Because our historical roots have been about social justice activism, we have been accused of not being rigorous and serious in our scholarship (Matthew 2016). In the modern university, metrics of success are used that emphasize neoliberal managerial 'reforms' including the dollar-amount of external grants and the number of peer-reviewed publications. Edwards and Roy describe the development of the neoliberal university by pointing out that, "Over the last 50

years...incentives for academic scientists have become increasingly perverse in terms of competition for research funding, development of quantitative metrics to measure performance, and a changing business model for higher education itself' (Edwards and Roy 2017, 51).

In this age of austere reforms, budget cuts are directed at the most vulnerable departments. Because of what we study, the subject of our work is also marginalized: "In theory, the new managerial practices appear as genderless and meritocratic. However, in practice, it seems that a new form of patriarchal structure has become endemic to academia. Therefore, it comes as no surprise when we are informed [of]...the faculty member at one institution who was not awarded tenure because her work was feminist (Cannella \& Salazar-Perez, 2012: 280)" (Sifaki 2016, 116). This attitude is not surprising; I have also experienced the dismissal of feminist scholarship in the academy. One such example is when, as a Fulbright Fellow, I volunteered to read student Fulbright applications and to provide feedback with a panel of other researchers. During a break after one session, a colleague began making fun of a student who had used intersectional theory to frame their statement of purpose; he said something to the effect that it was made-up "mumbo jumbo". Intersectional theory happens to be at the core of current 
day feminist scholarship, and I explained this to him. He wasn't convinced, but it was disconcerting that he felt perfectly comfortable demeaning a feminist theoretical framework; this attitude is precisely the patriarchal privilege that is at the center of research intensive universities.

It is not only the subject of our work, but also the speed of our work that places us at a disadvantage within the architecture of R1 universities that rely on hegemonic metrics. These institutions of higher education need to keep in mind that,

Good scholarship requires time: time to think, write, read, research, analyze, edit, and collaborate. High quality instruction and service also require time: time to engage, innovate, experiment, organize, evaluate, and inspire. This kind of slow work both defies and is threatened by the myriad demands on our time as academic laborers (Mountz et al. 2015, 1237).

For those of us who are called upon to do intensive diversity-related service work, even more of our time is encumbered. And we do this service work because we enjoy it and see it as part of our social justice commitment. Further, students may call on more of our time, as social-justice oriented departments attract students who, in addition to the regular academic support, call on us to provide personal, emotional, and activist support. Because women are generally seen as more nurturing and caring, "we are asked to teach and serve more than male faculty" (Turner Kelly and McCann 2014, 682). For example, during a high profile protest on our campus, students looked towards WGS and Black Studies departments for support. This work is not valued in R1 universities, and doing it can hinder us during tenure. Service and teaching, although often described as important, are frequently undervalued—if not outright ignored—in tenure metrics. At the same time, it is work that is important to our students and to the campus climate for marginalized people; thus, whether overt or covert, these practices of devaluation are exclusionary. 
I am in this structural conundrum of being in a Women's and Gender Studies department at a R1 university and in a conservative state where "doing" feminism and social justice oriented work is devalued. As a Latinx woman from a working-class background, my social identity as a brown woman in largely white institution also frames my experiences. Taken together, this spells an intersectional marginalized existence for women scholars of color who find ourselves in conservative states, in neoliberal universities, and in peripheral departments.

\section{Fomenting Fear}

The State of Missouri contributes to the reality of economic scarcity at the university where I work. The conservative legislature and governor have cut our budget, which is par for the course in states with drops in revenue from Republican dominated legislators. Public institutions of higher education are punching bags for those stereotyping academics with such characterizations as "indoctrinators," "politically correct," "elitists," "living in an Ivory Tower," and most recently, "snowflakes" who need "safe spaces" (Alterman 2016). For small and marginal departments - like WGS and Ethnic Studies - that tend not to produce large grants and focus our research and teaching on social justice related topics, there is fear that our departments could be critiqued and even closed.

The fear generated by scarcity is palpable at my university. The most marginal departments have the most to fear as they never know when a politically motivated attack results in a funding cut. As a result, departments like WGS end up functioning within a cloud of fear. Rather than feeling like we are in a position to resist the increasing corporatization and neoliberal metrics that place WGS departments at a disadvantage, the climate of fear can result in a pattern of acquiescence and, in the process, reproduce the hierarchical practices that are structurally based on the experiences of white, middle-class, heterosexual men. We give up our voice. 
When our students call on us to support them politically, as occurred with the nationally visible protest mentioned earlier, we have to make consequential decisions: Do we visibly support our students? Will we risk our jobs? What other consequences will we face? Even as an untenured faculty member I decided to accept an interview request about the protests from a news organization. I felt it was the right thing to do, even though I was afraid. A colleague in my department did an interview with a large national network and later received death threats for her support of our Black student protesters. Thus, we not only fear for our institutional safety as a department, but also for our personal safety.

\section{Social Media}

I am active on social media and have experienced the fear that my comments might be taken out of context and that I might be relentlessly harassed and my job threatened. This scenario has played out with a number of academics who are on social media and whose universities have not strongly stood behind them with the principle of academic freedom (Daniels and Stein 2017; Flaherty 2017; Quintana 2017). Last year at my institution the chancellor asked faculty to develop a diversity training program for incoming freshmen and transfer students. I presented on one of the courses that I teach and the subject of cultural appropriation. A student representing "Campus Reform," - a conservative blog-attended this event. Her goal was to deride diversity and she wrote a blog demeaning the presentation. It was retweeted by a conservative radio host, but luckily did not get much attention.

In this age of soundbites and tweets it is easy for motivated individuals to take statements out of context. Because of the attacks on my colleagues, I worry about being on social media, but at the same time it is a necessary space for me to engage with as I attempt to get my work read in and outside of academia. Social media has been where I have met other scholars, built 
collaborations, received scholarly invitations, and found a community of scholars of color who have positively impacted me. I may be harassed for tweeting about subjects like white supremacy from the general public (and local conservative pundits), but I should be able to count on my university to support my academic freedom. Whether I can, however, is not at all clear.

\section{Tenure and Promotion}

Another arena where departments and individuals function in fear is the tenure process, particularly because of the aspect of secrecy attached to it. Secrecy is different from confidentiality, and my critique is focused not on the identity of reviewers but on transparency throughout the process. One insightful view that secrecy supports a hierarchical university comes from David Lloyd, a professor of English, who writes:

'...tenure reviews and similar processes should take place in public with the candidate present and participant in the process. No other evaluation that relates to intellectual ideas takes place under cover of confidentiality, other than those whose intent is to safeguard established hierarchies' (Smith, 2010, para. 11).

In many cases, junior faculty do not know—much less—have input into the policies surrounding tenure. As I discussed the process among colleagues around campus, including a former chair of the campus tenure and promotion committee, I noticed much variation in tenure culture across departments. Ironically, in WGS the process adhered to the patriarchal schema of silence while in other departments it was described as "collaborative" and involving "advocacy" for the candidate. Why then did WGS adhere to a somewhat mythical ideal of secrecy? I suggest that the fear of being a small department and a target of the Alt-Right led to greater adherence to both written and unwritten "rules" of tenure. For example, a faculty member in Psychological Sciences explicitly defined his role as chair of a tenure committee as that of "advocate." Another colleague in the College of Arts and Sciences stressed that her tenure process with candidates is collaborative and asks for input. Instead, I experienced the "trust me" model, which rather than 
being collaborative is hierarchical. This is not the fault of individuals, but instead reflects the cloud of fear that surrounds marginalized departments in a neoliberal university. Although I know my colleagues have my best interests at heart, the "trust me" model in which relatively no information is shared about the process and input from the candidate is not sought out leaves women scholars of color, who already feel powerless in the institution, in an even more psychological and emotional precarious position.

\section{Feminist Mentorship in the Time of Trumpism}

Mentorship for academics of color is most needed in this precarious political environment where the Alt-Right is attacking our very existence on college campuses. A model of feminist mentorship that focuses on both personal and professional aspects of our lives provides a particularly beneficial framework as we navigate the hostilities directed at us in the current climate. As a woman of color in a WGS department, the feminist philosophy of linking the personal and professional is an everyday part of my life. Thus, it makes sense to emphasize a feminist frame in mentorship as well.

Two keys to feminist mentorship are (a) an intimate, collaborative relationship, which licenses (b) a critical lens to see and navigate the neoliberal institution for what it is. For example, Monica Casper describes mentorship the following way: "To this day I would be hard pressed to offer an ideal definition of mentoring, given that the role is a weird, beautiful, shapeshifting blend of parent, friend, colleague, expert, and generic authority figure. But one constant in all of my mentoring relationships, regardless of which side of the Starbucks table I'm sitting on, is that mentoring involves an exchange between two people" (Casper 2011, para. 4). Moss et al. (1999) describe feminist mentoring as, "Creating environments through collaboration, respectful exchange, listening, building alliances and group consultation processes assists in 
establishing trust and common political ground" (Moss et al. 1999, 422). At the center of feminist mentorship is collaboration. From the moment a candidate is hired into a WGS department, an important part of retention, integration and growth is collaboration. Therefore, it is important for marginalized departments like mine to recognize that advocacy and collaboration during the tenure process isn't only necessary, but push back is needed against the mythical objective notion of secrecy that if somehow "violated" (which is also not clearly define) is presented as compromising the "integrity" of the process. We must at least ask: Who does this secrecy during tenure benefit? And how does this secrecy uphold the hegemony of the institution? Functioning on fear may help alleviate some individual and departmental anxiety in the short term, but it will prevent long-term structural changes.

\section{Calling on Our Courage}

Marginalized departments like Women's and Gender Studies must navigate the rules of academic tenure without losing their mission. It is necessary to define what we (WGS departments) define as appropriate scholarship and pedagogy outside the metrics of the neoliberal university. One good starting point is the National Women's Studies Association $(\mathrm{NWSA})^{1}$ document on tenure and promotion which stresses the unique position of WGS departments. In fact, until WGS insist vehemently on their own benchmarks, scholars in these disciplines will be bound by the definitions set by other disciplines that do not have the same intellectual and societal goals as women's studies.

${ }^{1}$ http://www.nwsa.org/Files/Resources/2013-NWSA-TenureStatementFINAL.pdf 


\section{References}

Alterman, Eric. "Who's Behind the Right-Wing Assault on Public Universities?" The Nation, September 1, 2016.

Casper, Monica J. “The Intimacy of Mentoring.” The Feminist Wire, December 23, 2011.

Daniels, Jesse, and Stein Arelene. "Protect Scholars Against Attacks from the Right." Inside Higher Ed, June 26, 2017.

Echavez See, Sarita. "Talking Tenure Don't be safe. Because there is no safety there anyway." In Written/unwritten: Diversity and the hidden truths of tenure, edited by Patricia Matthew, 148-161. UNC Press Books. 2016.

Edwards, Marc A., and Siddhartha Roy. "Academic research in the 21st century: Maintaining scientific integrity in a climate of perverse incentives and hypercompetition.” Environmental engineering science 34, no. 1 (2017): 51-61.

Flaherty, Colleen. “Old Criticisms New Threats.” Inside Higher Ed, June 26, 2017.

Kelly, Bridget Turner, and Kristin I. McCann. "Women faculty of color: Stories behind the statistics." The Urban Review 46, no. 4 (2014): 681-702.

Matthew, Patricia A., ed. Written/unwritten: Diversity and the hidden truths of tenure. UNC Press Books, 2016.

Mountz, Alison, Anne Bonds, Becky Mansfield, Jenna Loyd, Jennifer Hyndman, Margaret Walton-Roberts, Ranu Basu et al. "For slow scholarship: A feminist politics of resistance through collective action in the neoliberal university." ACME: An International Journal for Critical Geographies 14, no. 4 (2015): 1235-1259.

Moss, Pamela, Karen J. DeBres, Altha Cravey, Jennifer Hyndman, Katherine K. Hirschboeck, and Michele Masucci. "Toward mentoring as feminist praxis: Strategies for ourselves and others." Journal of Geography in Higher Education 23, no. 3 (1999): 413-427.

Quintana, Chris. "A Professor Reflects on Her Time in the Eye of a Social-Media Storm." The Chronicle of Higher Education, April 16, 2017.

Sifaki, Aggeliki. "Which side are we on? Feminist studies in the time of neoliberalism or neoliberal feminist studies?" In Women's Studies International Forum, vol. 54, pp. 111118. Pergamon, 2016.

Smith, Andrea. “Confidentiality.” Religious Studies News, March 2010.

Turner, Caroline Sotello Viernes, and Juan Carlos González. "Faculty women of color: The critical nexus of race and gender." Journal of Diversity in Higher Education 4, no. 4 (2011): 199. 